\title{
Evaluation of Insecticides in Collars and Powders Against the Cat Fur Mite Felistrophorus radofskyi (Tenorio) on Persian Cats'
}

\author{
Irving Fox and Delfin de León ${ }^{2}$
}

\begin{abstract}
Collars impregnated with dichlorvos, naled, or stirofos on Persian cats for 10 weeks were ineffective against the cat fur mite, Felistrophorus radofskyi (Tenorio). Powders containing methoxychlor, carbaryl, or rotenone at cosages of $137-146 \mathrm{mg} / \mathrm{kg}$ applied to the fur once per week were also ineffective. When the dosage of the rotenone powder was increased to $293 \mathrm{mg} / \mathrm{kg}$, $100 \%$ control resulted after 5 weeks of treatment. Mild adverse reactions occurred from the dichlorvos collar (salivation) and the rotenone powder at the higher dosage (depression and loss of appetite). The cat wearing the naled collar died after 9 weeks with signs that suggested organic phosphate toxicosis.
\end{abstract}

\section{INTRODUCTION}

The cat fur mite was described in 1974, and so far has been found only in Hawaii and Puerto Rico $(6,3,5)$. Often very numerous on cats, and reported to cause pathology, it may be imported into continental United States at any time, if it is not there already. Cat fur mite infection is diagnosed by identifying the mite, which is recognized by the sclerotized bridge joining the prescapular and postscapular plates (fig. 1), a characteristic which is not present in other genera of the family Listrophoridae.

Of timely interest is whether any of the remedies often prescribed for infection with other ectoparasites would also control cat fur mites. The purpose of this study was to evaluate the effectiveness of collars impregnated with dichlorvos, naled, or stirofos, and powders containing methoxychlor, carbaryl, or rotenone, when applied to Persian cats.

\section{MATERIALS AND METHODS}

CATS

For the tests three Persians which were household pets and never let outdoors were used. Cat 1, a cameo male, aged 8 years, weighed $3.62 \mathrm{~kg}$; Cat 2, a pregnant silver female, aged 9 years, weighed $3.18 \mathrm{~kg}$; and Cat 3 , a silver female, aged 2 years, weighed $4.08 \mathrm{~kg}$. Cats 1 and 2 had been continuously infected with cat fur mites for at least 4 years, and Cat 3 had probably been infected since her birth.

\footnotetext{
${ }^{1}$ Manuscript submitted to Editorial Board November 18, 1980.

${ }^{2}$ Professor, Department of Microbiology and Medical Zoology, School of Medicine, Medical Sciences Campus, University of Puerto Rico, San Juan, P. R.; and Veterinarian, Agricultural Experiment Station, Mayagüez Campus, University of Puerto Rico, Río Piedras, P. R. The authors thank Capt. Curtiz R. Bartz, D.V.M., for helpful advice and Mr. Felix Liard for taking the photograph.
} 


\section{COLLARS}

The collars were obtained from commercial sources. The active ingre dients shown on the labels were dichlorvos, 2,2-dichlorovinyl dimethyl phosphate, 4.37\%; related compounds, $0.33 \%$; naled, 1,2-dibromo-2, 2dichloroethyl dimethyl phosphate, $10 \%$; and stirofos, 2-chloro-1-(2,4,5trichlorophenyl) vinyl dimethyl phosphate, $9.50 \%$. For a 10 -week period, Cat 1 wore the dichlorvos collar; Cat 2, the naled collar; and Cat 3, the stirofos collar.

\section{POWDERS}

The powders were also obtained from commercial sources. According to the labels, the active ingredients in methoxychlor powder were meth-

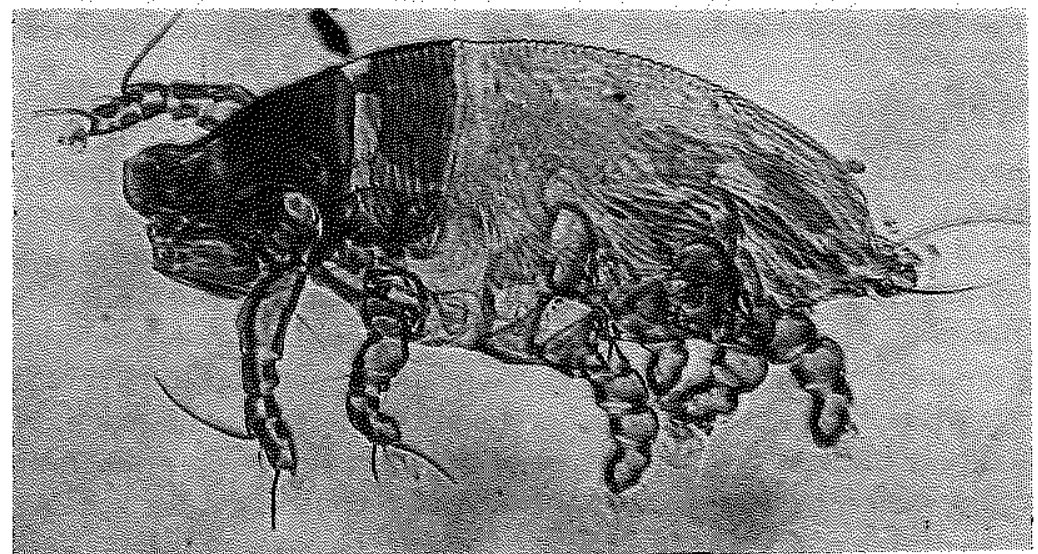

Fig. 1.-The cat fur mite, Felistrophorus radofskyi (Tenorio), male. Arrow indicates the sclerotized bridge joining the prescapular and postscapular plates, which characterizes the genus.

oxychlor, $2.50 \%$, pyrethrins, $0.06 \%$, piperonyl butoxide, $0.60 \%$; in carbaryl powder active ingredients were 1-naphthyl $\mathrm{N}$-methylcarbamate, $3.00 \%$, $2,2^{\prime}$-methylenebis (4-chlorophenyl), $0.50 \%$; and in rotenone, powder $1.00 \%$, other cube resins, $2.00 \%$, piperonyl butoxide, $0.30 \%$, pyrethrins, $0.03 \%$. The dosage of each powder was one-half teaspoon $(137-146 \mathrm{mg} / \mathrm{kg})$ applied to the fur. Another trial was made with rotenone powder at a dosage of one teaspoon $(293 \mathrm{mg} / \mathrm{kg})$.

The cat was combed thoroughly, the hairs removed from the comb, and placed in a Petri dish until enough hairs covered the bottom of the dish in a layer about $9 \times 9 \mathrm{~cm}$. After 2 or 3 days, when the mites had left the hair and concentrated on the bottom of the dish, the hair was removed. Under a stereoscopic microscope the mites were counted. 
Before each treatment, mites were collected from the cats and counted, and once per week, after collar or powder application, the mites were counted, over a period of 10 weeks. The standard for control was a significant reduction in the numbers of mites collected after treatment compared with the pretreatment count.

\section{RESULTS AND DISCUSSION}

Table 1 shows that none of the collars are effective against cat fur mites. Cats wearing collars impregnated with dichlorvos, naled, or stirofos were still heavily infested after 10 weeks, with the mite count of week 10 greater than the pretreatment count, and so was the average mite count per week. Similar results were obtained with powders containing meth-

TABLE 1.-Effect of collars containing dichlorvos, naled, or stirofos on cat fur mites as shown by the number of mites counted once per week in hair samples from Persian cats

\begin{tabular}{cccc}
\hline Week & $\begin{array}{c}\text { Dichlorvos } \\
\text { (Cat 1) }\end{array}$ & $\begin{array}{c}\text { Naled } \\
\text { (Cat 2) }\end{array}$ & $\begin{array}{c}\text { Stirofos } \\
\text { (Cat 3) }\end{array}$ \\
\hline $0^{1}$ & 34 & 2 & 55 \\
1 & 50 & 6 & 102 \\
2 & 97 & 119 & 33 \\
3 & 10 & 29 & 65 \\
4 & 13 & 18 & 44 \\
5 & 365 & 48 & 53 \\
6 & 104 & 322 & 77 \\
7 & 228 & 150 & 280 \\
8 & 425 & 197 & 102 \\
9 & 453 & 73 & 100 \\
10 & 152 & $D^{2}$ & 489 \\
Average & 190 & 96 & 135 \\
\hline
\end{tabular}

${ }^{1}$ Pretreatment count (before applying collar).

${ }^{2} \mathrm{D}=$ Died.

oxychlor or carbaryl (table 2). Rotenone at $137 \mathrm{mg} / \mathrm{kg}$ was also ineffective, but when the dosage was increased to more than double, or $293 \mathrm{mg} / \mathrm{kg}$, $100 \%$ control was obtained after 5 weeks of treatment. This control was maintained for the subsequent 5 weeks even though no further application of rotenone was made.

\section{ADVERSE REACTIONS}

Cat 2 died after wearing the naled collar for 9 weeks. The sequelae: About 6 weeks after the collar was applied, the cat gave birth to 2 dead kittens, and a live one, which died the next day. During the following 2 weeks she became depressed, motionless for long periods, sad, listless, and prostrate. Because of these signs the collar was removed. During the following week her appearance was very bad with her hair matted in 
spines. She showed other signs of severe illness: anorexia, dehydration, ataxia, and paralysis of the right hind leg. The collar had been applied on May 13 and the cat died on July 28, 1976. Necropsy report: "The cadaver was emaciated and matted with some uterine secretions. The stomach was empty except for some hair balls. No apparent changes were observed in the uterus, liver, lungs, kidneys, or small intestine."

Two other cats showed milder adverse reactions. Cat 1 during the 10th week of wearing the dichlorvos collar salivated excessively but recovered after the collar was removed. More than 2 years later this same cat, Cat 1 , was used for the experiment with rotenone powder at $273 \mathrm{mg} / \mathrm{kg}$. After

TABLE 2.-Effect of powder containing methoxychlor, carbaryl, or rotenone applied once per week on cat fur mites as shown by the numbers of mites counted in samples from Persian cats

\begin{tabular}{|c|c|c|c|c|}
\hline \multirow{2}{*}{ Week } & \multirow{2}{*}{$\begin{array}{l}\text { Methoxychlor } \\
146 \mathrm{mg} / \mathrm{kg} \\
\text { (Cat 1) }\end{array}$} & \multirow{2}{*}{$\begin{array}{c}\text { Carbaryl } \\
144 \mathrm{mg} / \mathrm{kg} \\
\text { (Cat 1) }\end{array}$} & \multicolumn{2}{|c|}{ Rotenone } \\
\hline & & & $\begin{array}{c}137 \mathrm{mg} / \mathrm{kg} \\
\text { (Cat 3) }\end{array}$ & $\begin{array}{c}293 \mathrm{mg} / \mathrm{kg} \\
\text { (Cat 1) }\end{array}$ \\
\hline $0^{1}$ & 181 & 88 & 67 & 267 \\
\hline 1 & 127 & 101 & 148 & 179 \\
\hline 2 & 288 & 150 & 79 & 38 \\
\hline 3 & 210 & 302 & 452 & 0 \\
\hline 4 & 88 & 115 & 101 & 0 \\
\hline 5 & 366 & 347 & 356 & $24^{2}$ \\
\hline 6 & 209 & 117 & 146 & 1 \\
\hline 7 & 290 & 96 & 194 & 0 \\
\hline 8 & 181 & 369 & 276 & 0 \\
\hline 9 & 114 & 279 & 34 & 0 \\
\hline 10 & 383 & 236 & 83 & 0 \\
\hline Average & 226 & 211 & 187 & 24 \\
\hline
\end{tabular}

'Pretreatment count (before applying the powder).

${ }^{2}$ The rotenone powder was not applied Week 5 and thereafter because the cat showed signs of toxicosis.

the rotenone was applied once per week for 5 weeks, he bcame depressed, suffered loss of appetite, and had difficulty in urinating. When the rotenone applications were stopped, he recovered. The stirofos collar, methoxychlor powder, and carbaryl powder caused no apparent sideeffects.

Of the three powders only rotenone at a high dosage was effective, but adverse reactions occurred. Wilkinson (7) reported that "derris" (another name for rotenone) may cause nausea, vomiting, and diarrhea in cats. Rotenone is well-known to veterinarians as an active ingredient in mixtures against ear mites and mange mites, and such mixtures have precautions on the labels. Powders should be similarly labeled.

Previous studies have shown that dichlorvos cat collars are not effective against ear mites (4). The present study shows that collars impregnated 
with dichlorvos, naled, or stirofos do not control cat fur mites. This study also suggests that naled collars are hazardous to Persian cats and to pregnant cats. Cat 2 showed clinical signs similar to those reported for dichlorvos collar toxicosis, such as depression, ataxia, and death $(2,1)$. Naled is an organic phosphate compound related to dichlorvos chemically; it would not be surprising if the toxic effects were similar. The collars of this study did not have warnings on the labels regarding Persians or pregnant cats. Some dichlorvos collars obtainable through veterinary supply houses do have such warnings. The consensus is against the use of collars impregnated with insecticides on long haired cats. It is unwise to picture Persians on the containers of the collars. The labels should warn against use on Persians, sick or convalescing cats, pregnant or nursing cats. Further, the clinical signs of toxicosis caused by cholinesterase inhibiting compounds should be indicated, with advice to consult a veterinarian if they occur.

Cat fur mites may become very numerous on a cat; but the damage they do is uncertain. It is not known whether they transmit any bacterial, viral, rickettsial, or mycotic disease, or cause allergy. According to the original description, severely infested cats in Hawaii exhibited "external symptoms in the form of mangy patches and scruffy appearance" (7). Since 1972 we have seen many cats in Puerto Rico which were infected with this mite, but most appeared to have a normal skin and pelage. For example, from January 2 to March 2, 1979, we studied 15 household cats brought to a veterinary clinic for various unrelated conditions, and found six of them infected with cat fur mites. Only one of these six cats had skin lesions of any kind, and the cause was not determined. Because more than one species of ectoparasite could affect an individual cat at the same time, it would be very difficult to separate exactly the pathological conditions each causes. It is possible that a more virulent strain of the mite occurs in Hawaii than that of Puerto Rico. And individual cats may vary in their reactions to the mite. In pursuing feline practice, veterinarians have the duty to find out whether this mite occurs in their localities. If so, they must determine the pathology, or lack of it, in each case, and decide on the need for therapy.

\section{RESUMEN}

Collares impregnados con dichlorvos, naled o stirofos puestos en gatos persas por 10 semanas fueron ineficaces para el combate del ácaro del pelo Felistrophorus radofskyi (Tenorio). Los polvos que contenían methoxych/or, carbaryl o rotenona en dosis de 137 a $146 \mathrm{mg} / \mathrm{kg}$ aplicados al pelo una vez por semana también fueron ineficaces. Cuando la dosis de rotenona se aumentó a $293 \mathrm{mg} / \mathrm{kg}$, se logró combatirlo totalmente a las cinco semanas. Algunas reacciones leves se observaron 
cuando se usó el collar con dichlorvos (salivación); y con el collar que contenía rotenona, en las dosis más altas, depresión e inapetencia. El gato con el collar impregnado con naled murió a las nueve semanas, con síntomas que sugerian una toxicosis causada por fosfato orgánico.

\section{LTERATURE CITED}

1. Allen, S. D., VanKampen, K, R., Brooks, D. R., 1978. Evaluation of the feline dichlorvos (DDVP) flea collar, Feline Practice 8: 9-16.

2. Bell, T. G., Farrell, R. K., Padgett, G. A., et al. 1975. Ataxia, depression, and dermatitis associated with the use of dichlorvos-impregnated collars in the laboratory cat. J. Am. Vet. Med. Assoc. 167: 579-86.

3. Fox, I., 1977. Felistrophorus, A new genus of mites on cats in Puerto Rico (Acarina:Listrophoridae). Proc. Entomol. Soc. Washington 79: 242-44.

4. - Bayona, I. G., Armstrong, J. L., 1969. Cat collars impregnated with dichlorvos ineffective against ear mites, J. Econ. Entomol. 62: 1503-04,

5. - and de León, D., 1979. Listrophorid mites on laboratory animals in Puerto Rico. J. Agric. Univ. P. R. 63(1): 84-6.

6. Tenorio, J. M., 1974. A new species of Lynxacarus (Acarina: Astigmata: Listrophoridae) from Felis catus in the Hawaiian Islands, J. Med. Ent. 11: 599-604.

7. Wilkinson, G. T., 1968. A review of drug toxicity in the cat, J. Small Anim. Pract. 9: 2132. 